\title{
Assessing the thermal-moisture functional performance of two sets of work uniform by S-smart simulation
}

\author{
Wenfang Song ${ }^{1}$, Albert PC Chan², Yueping Guo², Yang Yang ${ }^{2}$, Faming Wang ${ }^{1 *}$ \\ From 15th International Conference on Environmental Ergonomics (ICEE XV) \\ Portsmouth, UK. 28 June - 3 July 2015
}

\section{Introduction}

Construction workers are susceptible to heat stress in summer of Hong Kong. Wearing work uniform with good thermal-moisture functional performance (TMFP) is considered as one of the effective measures to protect workers from heat stress. However, there is a lack of scientific research to design workers' uniform based on heat-moisture engineering. This study aims to predict the TMFP of the selected fabrics by a S-smart system [1] under a stressful thermal environment.

\section{Methods}

The fabric characteristics of the examined knitted T-shirts (T1 and T2) and woven full-length pants (P1 and P2) were listed in Table 1 . The S-smart system was adopted to simulate TMFP of clothing with the input parameters listed in Table 1 (fabric characteristics) and Table 2 (body characteristics, activities and environmental condition) [2].
The simulation results were the human physiological responses, including the mean skin temperature $\left(T_{\text {sk }}\right)$ and core temperature $\left(T_{\mathrm{c}}\right)$.

\section{Results and discussion}

The computer simulation in Figure 1 showed that T2 and $\mathrm{P} 2$ had better thermal-moisture performance in terms of predicted core and skin temperatures than $\mathrm{T} 1$ and P1, respectively. However, only a marginal difference was presented. This is might due to the excellent OMMC and lower AR of T2 and P2 compared to T1 and $\mathrm{P} 1$, promoting evaporative heat loss more efficiently.

\section{Conclusion}

The computer simulation results indicated that $\mathrm{T} 2$ and P2 can improve thermoregulation by decreasing the predicted core and skin temperatures and microclimate humidity as compared to $\mathrm{T} 1$ and $\mathrm{P} 1$, respectively.

Table 1 Fabric characteristics T-shirt fabrics (T1 and T2) and full-length pants (P1 and P2).

\begin{tabular}{|c|c|c|c|c|c|c|c|}
\hline Fabrics & Fabric content & Weight $\left(\mathrm{g} \cdot \mathrm{m}^{-2}\right)$ & Thickness $(\mathrm{mm})$ & OMMC & AR $\left(\right.$ KPa.s.m $\left.{ }^{-1}\right)$ & WVP $\left(g \cdot \mathrm{m}^{-2} \cdot \mathrm{h}^{-1}\right)$ & $k\left(w \cdot m^{-10} C^{-1}\right)$ \\
\hline $\mathrm{T} 1$ & $100 \%$ cotton & 134.37 & 0.55 & 0.66 & 0.24 & 657.8 & 0.06 \\
\hline $\mathrm{T} 2$ & $100 \%$ Coolmax ${ }^{\circledR}$ & 146.40 & 0.62 & 0.8 & 0.06 & 593.1 & 0.06 \\
\hline P1 & $60 \%$ cotton blended with $40 \%$ polyester & 174.95 & 0.35 & 0.69 & 1.58 & 496 & 0.05 \\
\hline P2 & $100 \%$ cotton with Dry-Inside ${ }^{\circledR}$ technology & 185.26 & 0.48 & 0.86 & 1.96 & 530.6 & 0.06 \\
\hline
\end{tabular}

Note: OMMC-overall moisture management capacity; AR-air resistance; WVP-Water vapour permeability; k-heat conductivity

\footnotetext{
* Correspondence: dr.famingwang@gmail.com

'Laboratory for Clothing Physiology and Ergonomics (LCPE), the National

Engineering Laboratory for Modern Silk, Soochow University, Suzhou, China

Full list of author information is available at the end of the article
} 
Table 2 The design case in computer: body characteristics, activities and environmental condition.

\begin{tabular}{|c|c|}
\hline & The design case in computer simulation \\
\hline Body characteristics & $65.6 \mathrm{~kg}$ and $168.5 \mathrm{~cm}$ \\
\hline $\begin{array}{l}\text { Activity and environmental } \\
\text { condition }\end{array}$ & $\begin{array}{c}\text { Seated relaxed }\left(58 \mathrm{w} \cdot \mathrm{m}^{-2}\right) \text {, and }\left(30^{\circ} \mathrm{C}, 50 \% \mathrm{RH}\right) \text {-Standing activity }\left(163 \mathrm{w} \cdot \mathrm{m}^{-2}\right) \text {, and }\left(30.7^{\circ} \mathrm{C}, 65 \% \mathrm{RH}\right) \text { - Standing activity } \\
\left(248 \mathrm{w} \cdot \mathrm{m}^{-2}\right) \text {, and }\left(33^{\circ} \mathrm{C}, 54 \% \mathrm{RH}\right)-\text {-moving activity }\left(229 \mathrm{w} \cdot \mathrm{m}^{-2}\right) \text {, and }\left(34^{\circ} \mathrm{C}, 42 \% \mathrm{RH}\right)-\text { moving activity }\left(167 \mathrm{w} / \mathrm{m}^{2}\right) \text {, and }\left(32^{\circ}\right. \\
\text { C, } 41 \% \mathrm{RH}) \text {-recovery }\left(58 \mathrm{w} \cdot \mathrm{m}^{-2}\right) \text {, and }\left(31^{\circ} \mathrm{C}, 44 \% \mathrm{RH}\right)\end{array}$ \\
\hline
\end{tabular}
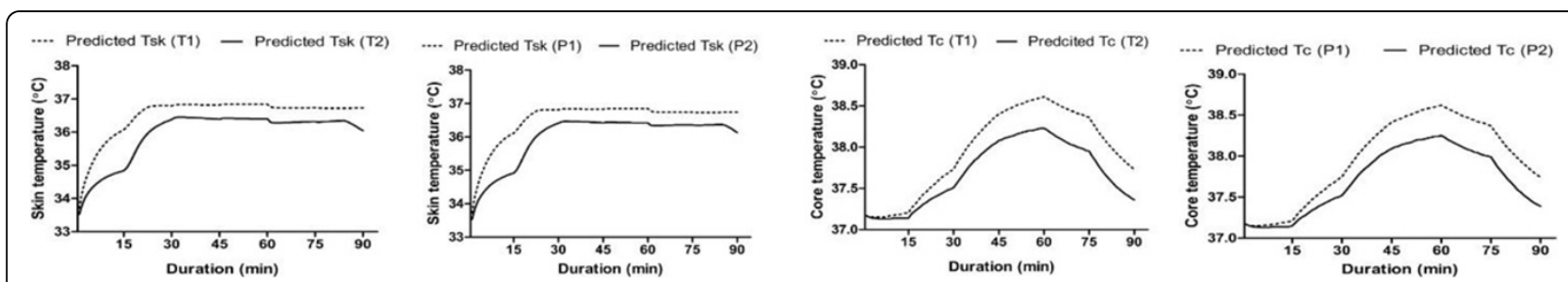

Figure 1 Comparison of core and skin and core temperature changes among T-shirts (T1 and T2) and pants (P1 and P2).

\section{Authors' details}

'Laboratory for Clothing Physiology and Ergonomics (LCPE), the National

Engineering Laboratory for Modern Silk, Soochow University, Suzhou, China.

${ }^{2}$ Department of Building and Real Estate, The Hong Kong Polytechnic

University, Kowloon, Hum Hon, Hong Kong.

Published: 14 September 2015

\section{References}

1. Guo YP, et al: Heat and mass transfer of adult incontinence briefs in computational simulations and objective measurements. International Journal of Heat and Mass Transfer 2013, 64:133-144.

2. Chan APC, et al: Evaluating a newly designed construction work uniform on heat stress. Textile Research Journal 2015, unpublished paper.

doi:10.1186/2046-7648-4-S1-A90

Cite this article as: Song et al:: Assessing the thermal-moisture functional performance of two sets of work uniform by S-smart simulation. Extreme Physiology \& Medicine 2015 4(Suppl 1):A90.

\section{Submit your next manuscript to BioMed Central} and take full advantage of:

- Convenient online submission

- Thorough peer review

- No space constraints or color figure charges

- Immediate publication on acceptance

- Inclusion in PubMed, CAS, Scopus and Google Scholar

- Research which is freely available for redistribution

Submit your manuscript at www.biomedcentral.com/submit
C Biomed Central 